\title{
La greffe générale: the voice of French facially injured soldiers
}

Article

Accepted Version

Gehrhardt, M. (2018) La greffe générale: the voice of French facially injured soldiers. Modern and Contemporary France, 26 (4). pp. 353-368. ISSN 1469-9869 doi:

https://doi.org/10.1080/09639489.2018.1458295 Available at https://centaur.reading.ac.uk/76229/

It is advisable to refer to the publisher's version if you intend to cite from the work. See Guidance on citing.

To link to this article DOI: http://dx.doi.org/10.1080/09639489.2018.1458295

Publisher: Taylor and Francis

All outputs in CentAUR are protected by Intellectual Property Rights law, including copyright law. Copyright and IPR is retained by the creators or other copyright holders. Terms and conditions for use of this material are defined in the End User Agreement.

\section{www.reading.ac.uk/centaur}

\section{CentAUR}

Central Archive at the University of Reading

Reading's research outputs online 


\title{
La Greffe Générale: The Voice of French Facially Injured Soldiers
}

\author{
Dr Marjorie Gehrhardt \\ m.i.s.gehrhardt@ reading.ac.uk \\ ORCID 0000-0002-8880-4286 \\ Department of Modern Languages and European Studies \\ University of Reading \\ Acknowledgements:
}

This work was supported by an EU INTERREG IVa grant (1914FACES2014 project).

Wordcount: 8,772 including abstracts in French and English, main text, key words, references and captions (not title page)

\begin{abstract}
English):
Like the combatants on the frontline, the wounded soldiers of the First World War wrote and published newspapers during the sometimes lengthy periods of time they spent in hospital. $L a$ Greffe Générale is the journal written by and for facially injured combatants treated at the Valde-Grâce military hospital in Paris. Throughout the eight issues released between December 1917 and July 1918, the voices of these men can be heard. Whilst the surgeons' perspective prevails in most remaining documents to do with French maxillofacial wards, La Greffe Générale gives an insight into the experiences of injury and treatment from the point of view of the wounded and convalescent combatants.

The specific challenges faced by facially injured men are reflected in their writings, as this article shows. At the same time, their newspaper is in itself an attempt to respond to some of these issues. Ultimately, the patients' publication reveals how gueules cassées, as French disfigured veterans came to be known, tried to collectively cope with their changed lives. The ethos reflected in, and fuelled by, La Greffe Générale played, this article argues, a significant part in the later constitution of the facially disfigured men's organization, the Association des Gueules Cassées.
\end{abstract}

\section{Abstract (French):}

Les blessés de la Première Guerre mondiale, tous comme leurs camarades au front, publièrent des journaux durant les périodes parfois longues de leur hospitalisation. Cet article analyse $L a$ Greffe Générale, le journal écrit et publié par les blessés de la face soignés à l'hôpital militaire du Val-de-Grâce, à Paris. Les huit numéros de cette publication donnent la parole à ces hommes que leurs blessures avaient souvent rendus physiquement incapables de s'exprimer. Quand la 
plupart des documents ayant trait aux services maxillo-faciaux révèlent la perspective des soignants, La Greffe Générale présente le point de vue des soldats blessés eux-mêmes. Les défis auxquels sont confrontés les blessés de la face y sont exposés, mais ce journal va plus loin en s'attaquant directement à certaines des difficultés évoquées. Cet article analyse la façon dont ces « gueules cassées » tentèrent de surmonter les changements causés par leurs blessures. La philosophie des blessés présentée dans La Greffe Générale, et encouragée par ce journal, ont contribué à la création quelques années plus tard d'une association regroupant les mutilés de la face, l'Association des Gueules Cassées.

\section{Keywords:}

First World War

facial injuries

soldiers' newspapers

veterans' organization

collective identity 


\section{Introduction}

Facial wounds, although they were sometimes only one among a number of injuries WWI combatants had received, seem to occupy a particular place in the 'hierarchy' of wounds. Georges Gelly, who was actively involved in supporting French facially injured veterans after the war, wrote that 'Il n'est pas de plus atroce héritage de la Grande Guerre que celui des blessures maxillo-faciales' $(1926,8)$. Indeed, to physical impairments such as loss of sight, difficulties to speak and eat (which could in turn lead to a weakened state of physical health), were added the life-changing effects of a disfigurement affecting what Heather Talley describes as 'a means of communication, a marker of identity and personhood, a signifier of social status and a form of capital' $(2014,13)$. According to Sophie Delaporte, between $11 \%$ and $14 \%$ of all French casualties received wounds to the head and face and ten to fifteen thousand of them remained severely disfigured as a result $(1996,30)$. Facial injuries were thus not an unusual occurrence in the First World War but thanks to the development of maxillofacial surgery, they became regarded with less fatalism. The need to provide specialised treatment was felt early on and a specialised maxillofacial unit was set up at the Val-de-Grâce military hospital, in Paris, at the end of August 1914, with more maxillofacial centres opening in the capital city and in other military regions in the following months. While administrative and medical reports by the head surgeons are available for most of these hospitals, the patients' perspective on their experience of wounding and treatment remains little-known.

Amongst the many, sometimes very short-lived, soldiers' publications, La Greffe Générale - as the journal of the wounded treated in the $V^{e}$ Division de Blessés at the Val-deGrâce was called - stands out. Facially wounded combatants, nicknamed les baveux because of their difficulty to control their saliva, spent months and sometimes even years undergoing treatment. The ground-breaking operations endeavoured by surgeon Hippolyte Morestin (1869-1919) and his colleagues at the Val-de-Grâce were interspersed with long phases during which the wounds were left to heal and the grafts to consolidate before another intervention could take place. Of key importance was the finding of occupations for the patients, whose families were not always able to visit them and whose frightening looks often deterred them from venturing outside the hospital. It is in this context that a small group of patients set out to write and publish a journal that, as this article shows, is both a reflection of the challenges faced by the patients, and an attempt to respond to them. Although research conducted in the main French archive repositories suggests that only eight issues of La Greffe Générale were ever published (between December 1917 and July 1918), the authors had great ambitions for their newspaper, which they saw as much more than a mere means of killing time.

The premature end of this journal may have been the result of the editors leaving hospital. The editorial committee supervising the publication remained indeed largely the same throughout the eight issues; this committee included well-known figures such as the scholar Gaston-Louis Malécot and the politician Marcel Stenay-Gatuing. Most pieces were however written by anonymous authors who sometimes took humorous pennames, such as 'Le Vieux Critique', 'Le Trépané' and 'Général O. P. Ré'. It is worth noting that at least two poems were written by female authors, signed 'A. NURSE' and 'Philè', the participation of women distinguishing La Greffe Générale from trench press. Reprints of articles from other newspapers and soldiers' publications are occasionally included, testifying to the links 
between this journal and other press titles, and perhaps also pointing to the editors' need to find additional content to fill the four pages of each issue.

Drawing upon existing studies on trench and hospital press, this article focuses on a publication concerned with a very specific group of men but which was nevertheless received as 'un véritable journal du front' (Chapelle 1917). La Greffe Générale presents the same historical interest as trench newspapers which, as Stéphane Audoin-Rouzeau underlines, 'were written there and then, and were unlikely to suffer from the distorting effects of recollection' (1992, 2). Some of the central themes in trench press can also be found in $L a$ Greffe Générale, however the setting in which the latter was written heavily influenced its contents and its tone. La Greffe Générale also distinguished itself from periodicals written by and for discharged soldiers such as Le Journal des Mutilés, Réformés et Blessés de Guerre (launched in 1916 and followed by several regional editions). More than the broad reach of the latter, it is its very practical dimension, with advice ranging from pensions to medical, legal and professional matters, that reveals a different set of concerns amongst discharged soldiers. In contrast, most Val-de-Grâce patients were still soldiers, sometimes likely to return to active duty. Their newspaper, like trench publications, is both 'a message to those at home' and a way of 'binding the battalion more closely together' (J.G. Fuller 1991, 12-13). This article also recognises the importance of the individual soldier's experience, especially in the case of the combatant whose distinctive facial features have been damaged to the point of threatening their sense of identity. It explores the hospital newspaper as a 'form of communal public expression' (Seal 2013,2) that helps frame individual experiences into a collective, largely optimistic, narrative. Being integrated into the sociability network of les baveux at the Val-de-Grâce, we argue, appears to be the first step towards reintegration into wider social networks.

The experiences of facially injured soldiers have rarely been explored despite a rise in interest in disability studies and in the medical history of the Great War. La Greffe Générale provides an original insight into these men's lives. Although censorship (and self-censorship) was at work, this publication is a valuable source that reflects the patients' perceptions of their situation and their concerns. As this article shows, the newspaper was also a way to collectively cope with the challenges facing gueules cassées, notably through the frequent use of humour. Psychologists have highlighted the role of humour in mitigating the adverse effects of mental and physical difficulties: 'humor, because it inherently involves incongruity and multiple interpretations, provides a way for individuals to shift perspective on a stressful situation, reappraising it from a new and less-threatening point of view' (Rod Martin 2007, 282). This article analyses the use of humour as a coping mechanism by men whose chose 'Rire quand même' as their motto, in reference to the psychological and physical obstacles that could have prevented them from smiling. We also show that the emergence of a group awareness can be traced back to the Val-de-Grâce hospital. The resilience, the patriotism and the solidarity expressed, and encouraged, in La Greffe Générale later inspired the Association des Gueules Cassées (1921). The Union des Blessés de la Face et de la Tête, as it was officially named, focussed on supporting disfigured veterans practically and psychologically. It also shaped a collective image of the facially wounded as men who had been profoundly affected by the war but whose sense of humour, love for their country and determination to overcome their circumstances had enabled them to reintegrate into French society, and ultimately to become a flourishing organisation (Gehrhardt 2015, 150-158). 


\section{A reflection of, and on, the lives of facially injured soldiers}

\section{Practical and physical concerns}

In his analysis of French trench newspapers, Audoin-Rouzeau (1992) identifies daily life as the most frequent topic discussed by soldier-writers. La Greffe Générale shares this traditional theme of the trench press genre as the texts and images it features extensively describe the surroundings in which the patients live and the pattern of daily life. Focussing on trivial matters such as the maintenance of the buildings, helps patients forget, at least for a time, about the painful operations taking place at the Val-de-Grâce. For example, the repainting of the entrance portal leads a contributor to protest against the new appearance of the hospital, not unlike that of a department store (La Greffe Générale (hereafter referred to as LGG) 2 [January 1918], 2). Patients-writers are keen observers of the physical space of the hospital, part of the military world but set in the middle of Paris. A statue of Ann of Austria, who had the Val-de-Grâce abbey built, in the hospital gardens is thus reported as upsetting the patients, for whom the Austro-Hungarian Empire is the enemy (LGG 2, 2). Food is also a frequent theme: mashed potatoes are presented as the 'plat national' (LGG 3 [February 1918], 1) in the hospital, an implicit reference to the fact that many patients could not eat solid foods due to their injuries. Everyday concerns and anecdotes participate in creating the sentiment of a shared experience, specific to facially wounded combatants. This emphasis on trivial matters also shifts the focus away from more serious issues such as surgery and the everpresent risk of death.

The medical treatment of stories, which sometimes have nothing to do with injuries or treatment, however distinguishes La Greffe Générale from frontline publications. The description of the repainted hospital portal thus ends with the following prognosis: 'L'état du portail devient très inquiétant. La suppuration de plus en plus abondante a nécessité un nouveau grattage. Des complications sont à redouter...' (LGG 2, 2). Likewise two patients envisage the possibility to subject little-esteemed political leaders to a face transplant and give them 'une face d'honnête homme' (LGG 2, 2). To this, another contributor replies that in such cases a graft is not enough, amputation being the only solution. The way in which topics that are otherwise similar to those addressed in frontline press are treated is thus specific to the medical setting in which La Greffe Générale is written and it enables its authors to bear witness to their own particular experience of war, wounding and care. In highlighting the distinctiveness of their situation, disfigured patients are setting themselves apart from soldiers on the frontline and from other disabled veterans.

Aspects of the medical treatment itself are another frequent theme: from the arrival of new patients to dialogues overheard in the operating theatre, to the outbreak of diphtheria in the service, the patients' therapeutic journey is described. Unlike medical reports, however, the stories told by the patients are free of technical jargon and often humorous in tone; as will be shown later this use of humour contributed to diffusing the anxiety surrounding treatments that could fatal. The absence of technical jargon besides makes the journal accessible to the general public. La Greffe was indeed intended to be circulated outside hospital, and reports in contemporary newspapers testify to its reach beyond the Val-de-Grâce. Through the use of simple language, no linguistic barriers are created between the readers from outside the hospital and the patients and staff more familiar with this lingo. In fact, specialised medical 
lexicon is presented as a source of confusion for the patients themselves, as shown in a letter supposedly written by a patient, Pitou, to his parents (LGG 5 [March 1918], 3). In it, he describes how, upon his arrival at the Val-de-Grâce hospital, he was washed with 'père manganate' (permanganate), received an injection of 'p'tit tête d'Annic' (antitétanique) to prevent him from contracting 'la tête en os' (tétanos), and was bandaged with 'kronpress' (compresse).

The language used by Pitou reveals both the potential lack of understanding between doctors and patients, and the limited intervention of medical staff in La Greffe Générale. In his discussion of British hospital magazines, Jeffrey Reznick (2011) notes that military authorities had a degree of control over the journals through the involvement of hospital personnel in the editorial process. In La Greffe Générale, the voices of patients prevail, although staff members are not completely absent. While existing literature often highlights the distant, even conflictual relationships between doctors and soldiers (see for example Ana Carden-Coyne 2014), the authors of La Greffe Générale seem to enjoy a harmonious relationship with staff. Self-censorship amongst the authors who might not want to jeopardise their newspaper through expressing criticism may account for the absence of negative comments, however the unfailingly positive tone suggests that the feelings expressed are genuine. The length of maxillo-facial treatment is a likely contributing factor in the development of close relationships between staff and patients. Patients thus repeatedly state their admiration for their surgeons and the first two issues are dedicated respectively to 'Celui dont la science et le dévouement nous ont rendu l'espoir' (LGG 1 [December 1917], 1), i.e. surgeon Hippolyte Morestin, and to the 'dignes collaborateurs de Monsieur le Professeur Morestin' (LGG 2 [January 1918], 1). More than the surgeons' medical prowess, their achievements are described in terms of the psychological impact they have on the patients: they restore hope and make life worth living again. Historians such as Katherine Feo (2007) and Julie Powell (2016) have challenged this positive assessment of the results attained through surgical reconstruction: facial prosthetics, they note, were often perceived as necessary to make up for the substantial loss and reassert the disfigured men's masculinity (Powell 2016, 609). According to Feo, however, the still masks' 'inadequacy as a method of social rehabilitation' (Feo 2007, 17) soon became obvious. The optimistic tone of La Greffe nevertheless testifies to the men's perception of significant improvement, and to their gratitude towards the surgeons. The 'debt' owed by facially wounded soldiers would later be re-emphasised by the Association des Gueules Cassées, who for instance supported a request from ex-patients that part of the rue du Val-de-Grâce be re-named in the honour of Morestin, 'ce Bienfaiteur de l'Humanité' (Bulletin de l'Union des Blessés de la Face, 6 [February 1923], 1).

If surgeons did not publish articles in La Greffe Générale, a number of contributions about, or by, ward orderlies and nurses can nevertheless be found, further reflecting the close links between staff and patients. The third issue is dedicated to nurses, described as 'Fées de nos douleurs, tendres, consolantes' (LGG 3,1). The articles written by, or about, them are telling of the combatants' esteem, and of the nurses' affection for the wounded. A poem written by 'A. Nurse' thus praises the sacrifice made by her patients and whilst apologising for the boldness of her poetic endeavour, she asks her readers ' $Q u$ 'en vos coeurs elle ait une place / L'infirmière du Val-de-Grâce / Qui vous admire et vous rend grâce' (LGG 2, 3). This is a request to which the men responded favourably, as shown in the example of Pitou, who 
writes in his letter that 'C'est p'têt' un peu fort comme culot, mais j'vais oser dire à mes infirmières qu'all [sic] sont toutes dans mon Coeur' (LGG 5, 4).

The discourse held in La Greffe Générale is thus very respectful, even eulogistic, towards the medical staff, which is not surprising considering that it was published in a military hospital and subject to censorship rules. However the criticism levelled on occasions against political leaders suggests that the authors did not refrain from expressing their discontent, and that their praise for doctors and nurses was genuine. The overall bias is 'Clemenceauphile' (LGG 3, 2); political discussions are however discouraged in La Greffe Générale, a position that the Association des Gueules Cassées would later formalise by explicitly banning political and religious discussions in its statutes.

\section{Psychological and social challenges}

If the portrayal of life in the hospital depicts harmonious relationships between staff and patients, the newspaper also mentions the negative responses of visitors to the hospital and of passers-by met by patients on the streets of Paris. While presenting an overall optimistic view of the men's future, La Greffe Générale also reflects their fear of, and sometimes anger at, other people's reactions. In the first issue, the Sunday afternoon visiting time is described as 'la visite des fauves' - the beasts in this case may equally be the patients or their visitors (LGG 1,2). This article highlights the soldiers' dislike at being treated with pity and commiseration by well-meaning guests. Another article gives the authors a chance to 'educate' the public on which responses are particularly unwelcome:

Ce n'est pas la peine de rappeler sans cesse, par votre compassion inopportune, aux blessés du visage, que leur admirable médecin n'en est encore qu'à la première phase de la cure, et qu'ils ne sont pas encore absolument séduisants. Ils le savent. Et même ils ne le savent que trop (LGG 2 [January 1918], 1).

Disfigurement is presented as a temporary condition that surgeons will repair. In fact, the outcome was not always positive and this adds to the ambiguity of the discourse held in $L a$ Greffe Générale: facial wounds are at the same time solemnly praised and brushed off as unimportant. Disfigurement is described both as a reason for pride and as a source of distress. The authors claim that they want to forget about their mutilation whilst simultaneously urging fellow patients to bear their injuries with confidence. This ambivalent discourse is telling of the men's difficulty to come to terms with their disfigurement, and of concerns about the image they will project to the rest of the world. Ana Carden-Coyne writes about British veterans that 'Disabled and mutilated bodies symbolized entwined stories of victory and defeat' $(2009,75)$; a similar phenomenon can be observed in France, where the Union des Blessés de la Face et de la Tête would later combine the images of victims and heroes in its fundraising campaigns, successfully portraying disfigured men as the worst victims of the war, who yet managed to overcome their trauma together (Gehrhardt 2015).

In the wards, the wounded rarely saw their own faces, which remained hidden behind bandages or invisible because mirrors were banned. Nevertheless, far from being a taboo subject, the mutilated face is frequently described, sometimes with surprising directness. The authors call themselves 'amochés', 'blessés de la trogne' (LGG 1,1) and 'faces ravagées' 
(LGG 1, 3), in a self-deprecating way that heralds the adoption of the derogatory 'gueule cassée' [broken faces] by the Association des Gueules Cassées. In particular, a poem by Stenay depicts the wounded face in very graphic terms: 'Leur face n'est plus qu'une chose sans nom / Un amas monstrueux de chairs déchiquetées / De pansements, de pus, de fièvre empaquetées / Euvre d'amour teinte d'horreur par le canon...' (LGG 6 [April 1918], 3). Writing about his catastrophic injuries might be a way for Stenay to distance himself from them, but the fact that the patients-writers inhabit a space where surgical reparation prevails helps frame these graphic depictions into a positive therapeutic narrative: these terrible wounds are being treated.

The apparent lightness with which patients talk about their wounds should not hide the psychological difficulties they were encountering. 'La lutte contre ce vieux frère de Cafard' (LGG 1 [December 1917], 1) is presented as the main goal of the journal, the bellicose terminology reminding readers that the wounded remain combatants. The fight in which Val-de-Grâce men are engaged is however not against machine guns and shells but against depression. While difficulties to cope with disfigurement and its consequences are mentioned, the tone nevertheless remains positive throughout. A series of four sketches even suggests that facially injured servicemen end up looking better than before they were wounded. Entitled 'Un profiteur de la guerre', this series turns the usual conventions upside down: a man is represented having his looks and spirits significantly improved by his facial injuries and his time at the Val-de-Grâce:

\section{FIGURE 1}

These drawings place the injured man in a positive narrative that sees his wounds ultimately benefitting him rather than disabling him. Although this series is overly optimistic, in general the authors do not shy away from evoking the physical and psychological difficulties faced by facially injured combatants. These challenges are articulated, albeit sometimes in an indirect way, in the hospital newspaper, which in turn participates in inscribing their experience in a narrative of reconstruction. The contents and the very existence of La Greffe Générale are also revealing of a growing sense of community amongst patients, united by an experience that sets them apart from other wounded servicemen.

\section{La Greffe Générale: A response to the issues faced by wounded combatants}

The Val-de-Grâce newspaper was in and of itself a response to some of the challenges faced by the wounded. In particular, writing and reading La Greffe Générale contributed to lifting the men's spirits, it fostered a sense of solidarity between patients and it helped prepare their return to civilian life. The usefulness of La Greffe Générale was acknowledged by the Chef du Service des Journaux du Front; in a letter to the editors he underlines: 'Votre oeuvre [...]

qui saura joindre l'utile à l'agréable, aura une excellente influence sur tous les soldats [...]. Elle les aidera à supporter mieux encore les souffrances morales dont quelques-uns pourraient ressentir les atteintes' (Chapelle 1917). La Greffe Générale thus represents an attempt to address the problems encountered by facially injured men. 


\section{Humour: a weapon against le cafard}

La Greffe Générale kept the authors occupied between operations and provided entertainment to both contributors and readers. One notable feature is the gaiety that pervades most of these writings, this humour a way to release the nervous energy built up in patients' lives since their injuries. Jacqueline Garrick underlines the physiological benefits of laughter (2006, 172), but she also emphasises the importance of humour as a coping mechanism: 'During the trauma, humor may have been a tool of survival; in the recovery process, it can be used as a tool for surviving and thriving as well' (Garrick 2006, 181). In the early twentieth century already, Sigmund Freud (1905), had suggested that humour could help let off suppressed emotions; this seems particularly apt when considering the negative feelings of pain, fear and worry developed by facially injured patients and reported by contemporary commentators. The title of the newspaper itself is a pun playing on the similarity with grève générale, in reference to the strike against boredom and depression that the patients have declared (LGG 1, 3). The journal also launched an 'Impressions du Chloroformé' contest, aimed at collecting readers' stories of being under anaesthesia. It thus deals with a serious topic - undergoing operations whilst being unconscious - in a light tone, calling all the 'Chevaliers du Billard de France et de Navarre, Chevronnés de l'Opération' (LGG 1,4) to contribute. The patients are here portrayed as medieval heroes, knights who are far from passive in their treatment. Likewise, a poem, parody of Edmond Rostand's Cyrano, talks about damaged looks in comically lyrical tones 'Face qui jamais se renfrogne', 'Oeil de cristal' and 'Bouche en trou' are mentioned (LGG 1 [December 1917], 1). Popular quotes are given a new twist, such as Karl Marx allegedly claiming that 'A chacun sa part de Prothèse! Nous réclamons l'oeil en verre pour Tous!' (LGG 7 [May 1918], 4) while 'Après la Bataille: Un petit verre de "Morestine-du-Val"!' is presented as 'souverain contre les mutilations faciales' (LGG 8, 4). In addition to being jokes, these short phrases contribute to trivialising facial injuries, making them appear commonplace and easily curable. Such comments may be interpreted as examples of 'inappropriate' humour, as defined by Garrick $(2006,177)$ that reveals a will to distance oneself from a painful memory, or even a form of denial. On the other hand, this downplaying of the life-changing impact of facial wounds can also be regarded as reflecting the hope that facial wounds will be successfully repaired. Through trivialising their injuries and their consequences, the soldiers are reacting against the image of helpless victims, and the newspaper, through publicising a humorous interpretation of potentially very serious events (for example surgical operations), helped establish a positive framework for individuals to approach their own traumatic injuries. La Greffe Générale, it could be argued, was a platform that could be compared to modern-day therapy groups, blogs and forums, in which 'the sharing of humorous memories [...] [provides] participants with a new perspective for viewing the memories that haunted them (Garrick 2006, 170)'.

If the subjects about which the authors joke, for instance their wounds and scars, are specific to the context in which the newspaper is written, La Greffe Générale shares its humorous tone with other frontline publications (Fuller 1991, 17). The cheerfulness of facially wounded combatants has nevertheless surprised readers ever since 1917, as noted by journalist René Benjamin in Le Journal: 'Avoir eu les trois-quarts de la face emportés par un éclat de marmite, et rire avec ce qui reste, n' est-ce pas admirable et poignant?' (Benjamin 1917, 1). Likewise, a review published in Le Figaro comments on the incongruity of the motto, 'Rire quand même', chosen by the editors of La Greffe Générale, and underlines the contrast between the situation of facially injured combatants and the attitude they promote. This combination is presented as revealing the true mark of heroism: 'On nous a répété bien des mots héroïques. Y en a-t-il un qui soit plus frappant que celui-ci: Rire quand Même! 
Proféré par des hommes qui n'ont plus ce qu'il faut pour rire?' (LGG 4 [February 1918], 4). The journalist's tone is positive, even admiring, he nevertheless acknowledges that the slogan may only partly reflect the state of mind of the patients, or echo the sentiment of some of the men only. This discrepancy has not ceased to surprise and in her 1996 essay, Delaporte notes the 'gaieté un peu étrange' in La Greffe Générale, interpreting it as 'une forme de dénégation du handicap' (Delaporte 1996, 135-136). Rather than a refusal to face the facts, the newspaper's position appears to be a provocation, an attempt to overcome the trauma and to encourage others to not take disfigured combatants at 'face value'. This resilience is another common point with the attitude later promoted by the Association des Gueules Cassées, who chose 'Sourire quand même' for its motto.

Through jokes and exhortations to fight off le cafard, La Greffe Générale thus participates in the battle against depression. Benjamin describes La Greffe Générale's main purpose as 'tuer le cafard' (Benjamin 1917, 1): the laughter of the facially injured soldier is ultimately a sign of his continued involvement in the war against discouragement and the devastating effects of the conflict on men's bodies and minds. Humour is also presented as a way of showing one's patriotism. Refusing to give up is described in La Greffe Générale and in reviews as a typically French attitude: 'Vous gardez la gaieté française. Sur votre lit, sur votre chaise, Vous blaguez, riez et chantez, Et gauloisement plaisantez, Comme à la foire de Beaucaire...' (Chuquet 1918) and 'Le Rire éternel du bon pays gaulois [...] anime étrangement tous ces masques difformes' (Stenay-Gatuing 1918). According to Stenay, soldiers and veterans have a right to laugh: this is a sign that the war has not crushed their spirits. To him, 'la "franche" gaieté' is epitome of the French character, it is a 'source d'héroïsme et de génie' (LGG 8, 3). In defining 'gaieté' and 'rire' as essential features of the French spirit, Stenay emphasises what he sees as a shared trait between facially injured soldiers, combatants in general and the rest of society. However the latter have, it appears, lost this fundamental French feature and it is La Greffe Générale's responsibility to re-ignite it. The wounds received by gueules cassées do not leave them lacking, rather the wounded are at the forefront of the fight to defend France, her territory and her ideas. In emphasising this positive message, La Greffe Générale re-asserts some features of traditional masculine identity. At a time when masculinity was still strongly associated with militarism and nationalism (Mosse 1998), facial wounds raised questions pertaining to the gueules cassées' ability to fulfil traditional roles such as that of warrior at the service of his country but also of breadwinner at home. In presenting them as heroic combatants serving France even from their hospital beds, the newspaper helps alleviate concerns regarding the 'masculinity' of men whose capacity to reintegrate into familial, economic and social circles had been challenged.

\section{Fostering esprit de corps}

High spirits and a sense of humour are presented as characteristics shared by all the facially wounded men at the Val-de-Grâce. The collective prevails over the individual, at the hospital like on the front and the choice of publishing most contributions anonymously adds to the lack of individuation of the writers. For facially wounded men, the group can act as a protection: when he is surrounded with other disfigured men, the gueule cassée does not stand out, he is 'normal' in the sense that he resembles people around him. It is therefore no surprise that La Greffe Générale should encourage a strong sense of comradeship between 
the men (no female patients are mentioned), a phenomenon described by Jay Winter as 'kinship' (1999, 40-60). This can be accounted for by a common experience of the war and of wounding, but also by the long time spent together during treatment and a shared sense of humour (Garrick 2006, 170). Sophie Delaporte thus highlights the importance of hospitals in the re-socialisation of disfigured combatants : 'la sociabilité entre les défigurés de la Grande Gerre naquit là, dans les hôpitaux, Elle est le fruit d'une souffrance partagée, d'un passage en commun à travers une immense épreuve physique et morale' $(1996,130)$. The newspaper served to articulate and nurture these links, even beyond the Val-de-Grâce. In practical terms, La Greffe Générale was a means to provide material help to fellow patients: when a dying man's family cannot afford to travel and visit him one last time, the newspaper subscribers fund their trip. In the article reporting this event, the focus is not on the dying man but on the solidarity shown by his comrades and on the role played by the newspaper in raising the necessary money. The financial profits from La Greffe Générale were also meant to procure material comforts: 'l'argent des abonnements servira à acheter des cigarettes et des bouquins aux camarades dont le traitement est interminable' (Benjamin in LGG 3, 4).

Leaving the hospital did not sever these links as shown in a poem honouring the memory of pilot Gilbert Triboulet, who went back to the front after leaving the Val-de-Grâce (LGG 2, 3). The strong bond between him and his ex-fellow patients remained, even beyond death. Triboulet is depicted as a hero whose patriotism led him to return to combat before his wounds were completely healed. This example also suggests that little distinction was made between men of different ranks and corps. Triboulet was an adjutant in the air force who was studying law before the war; on the other hand Pitou's aforementioned letter indicates that his level of literacy was minimal. An anonymous general writes in La Greffe Générale about his outings with a fellow patient, an infantryman, whilst the future Association des Gueules Cassées president, Colonel Yves Picot, omits his rank when signing his article. Soldiers from the French empire are also mentioned, suggesting that they were in contact with French metropolitan servicemen. In this respect the Val-de-Grâce differs from The Queen's Hospital, the largest maxillo-facial hospital in Great Britain, where separate wings were reserved for different nationalities. This apparent willingness to overcome traditional social boundaries at the Val-de-Grâce foreshadows the openness of the Association des Gueules Cassées, which saw the common experience shared by its members as more important than their rank or social class. The organisation's first president, Yves Picot is reported to have spent his free time with facially wounded soldiers rather than with fellow officers who had suffered from other wounds (Roubaud 1960, 59).

The feeling of forming one group, distinct from the rest of society, even from other wounded soldiers, extends to facially injured men treated in other hospitals. Thus, the fourth issue of La Greffe Générale is dedicated 'A tous nos Camarades les "faciaux" de France' (LGG 4, 1). The term used by the authors to refer to the members of their group -'les faciaux' - reduces the wounded combatants to their faces and echoes the medical jargon employed to communicate concisely the anatomical location of the wound. Whilst Val-deGrâce patients seem to have appropriated this term (they still use it between inverted commas), it is not the name they claimed for themselves in the long term. Rather, they became known in France as les gueules cassées a more informal, less technical, name but which distinguished them from other mutilés. 


\section{The mediating role of La Greffe Générale}

If La Greffe Générale claims a distinct identity for facially disfigured men, the newspaper is also conferred the role of building bridges between this group and other people. Although the wounded are singled out, they are also part of this larger group, les combattants. The support of trench newspapers is acknowledged and in turn excerpts from La Greffe Générale appear in frontline titles such as La Baïonnette and Le Bochofage. The wounded men's sentiment of still belonging with their 'brothers' on the front shows through, especially when it comes to denouncing civilian press. In April 1918, shortly after the start of the German Spring offensive, La Greffe Générale claims to report on some of the civilian journalists' views on the latest development in the conflict for the benefit of the men in the trenches (LGG 6,1-2). The authors declare themselves unable to equal the newspapers' 'bourrage intensif', because they have not been at the rear for long enough. The difference in experience between civilians and combatants is thematised, and although the authors describe themselves as belonging to the latter group they still show an awareness of being in a singular position. Their separation from civilians is also visible in a sketch drawn by Marcel Mime and published in the third issue (LGG 3, 3), which depicts an elegant woman complaining about the restrictions imposed on civilians to a man whose head is covered in bandages. Her final statement that 'La guerre nous aura coûté les yeux de la tête' is particularly ironical considering the wounded man's loss of sight. This drawing thematises the so-called gap in experience and understanding between soldiers and the Home Front, returning soldiers being later described as 'silent' and 'poorer in communicable experience' (Benjamin 1936, 362). Social reintegration is however not portrayed as a source of concern for facially wounded men, the few stories revolving around this theme suggesting that the men will be welcomed back. The story of Bélagnon, whose disfigurement led him to marry two women instead of one, and earned him a job as a postman, is telling of this optimistic outlook on disfigured men's prospects. The reality could be different, however, and the absence of acknowledgement that professional and economic reintegration could be challenging suggests that the newspaper's authors sought first and foremost to provide reassurance to their comrades. The existence of écoles de mutilés and écoles de rééducation professionelle is not mentioned, even though by 1917 the professional rehabilitation of disabled veterans had become a key issue, as shown in publications addressed to discharged and reformed veterans such as Le Journal des Soldats Blessés aux Yeux and Journal des Mutilés, Réformés et Blessés de Guerre. This could also suggest that, unlike blind soldiers or amputees, disfigured ex-servicemen did not expect to need re-training, the aesthetic prejudice being often greater than the functional damage. This reassuring view besides communicated to the outside world a normalised vision of the future of gueules cassées, who appeared possibly able to return to their previous occupation.

If facially injured patients are physically removed from the frontline, they still think like, and identify with, frontline combatants. The ambiguity of the wounded men's place is aptly summarised by chief editor Stenay-Gatuing, who describes himself and his comrades as 'les presque-civils de l'arrière-front' (LGG 4, 1). The bombing of Paris particularly reminds patients that they belong to a group who, unlike civilians, has experienced life on the frontline: 'quelques mois de calme et de sécurité' spent at the hospital 'n'avaient pas complètement étouffé nos instincts de combattants' (LGG 4, 1). With the intrusion of a threat usually associated with the battlefield into a Parisian hospital, the blurring of boundaries in terms of the patients' identity is highlighted. The wounded, who sometimes come across as 
having developed an identity of their own, neither soldiers, neither civilians, are in this instance 'plus prêts que jamais à la lutte féroce et sans merci' (LGG 4, 1). Even if the authors are away from the immediate danger of the frontline, death is nevertheless very present. When frontline soldiers go over the top, Val-de-Grâce patients go to the operating theatre; both are however exposed to danger.

Reznick notes that English hospital magazines reveal the patients' 'collective sense of being a class apart from non-combatants in British society' (2011, 65). A similar in-between zone is however not perceived, or presented, as passively inhabited by the facially wounded, who themselves are on a journey of physical and psychological reconstruction. Instead, the authors of La Greffe Générale claim for themselves a role of mediation between combatants and civilians. Suzannah Biernoff notes the 'physical and psychological isolation of patients with severe facial injuries' $(2011,668)$ in the British context, a result, she argues, of the 'culture of aversion' surrounding facial injuries. The French veterans' newspaper made these injuries legible to the public, the textual medium providing a means to decode the emotions (or at least the feelings the wounded wanted the public to know about) of the faceless men when translating visual cues was more difficult. The literary encounter mediated by La Greffe Générale could serve as a prelude to face-to-face meetings, which could be more challenging due to the nature of facial injuries.

Whilst La Greffe Générale was a way for facially injured soldiers to communicate with one another and with people outside the hospital, its authors also ambitioned to facilitate communication between civilians and combatants more generally. The trustworthiness, honesty and lack of ulterior motives of Val-de-Grâce patients is emphasised, making them look like ideal intermediaries between two groups who seem unable to communicate with each other. La Greffe Générale is presented as the medium through which facially injured soldiers will fulfil this mediating role. This is done in part through the close links developed with the press, ensuring the hospital newspaper a distribution outside the Val-de-Grâce. Le Figaro editor Louis Latzarus thus wrote the editorial of the second issue; in it he addresses not only facially wounded men, but society at large. Le Gaulois and Le Figaro welcomed the Val-de-Grâce publication, describing it as a 'nouveau confrère' (Le Gaulois in LGG 8,4). The civilian press expressed their admiration, the quality of the journal and of the men it represents merging into one single picture of patriotism, humour and resilience. The active support of 'la grande Presse parisienne' (LGG 1,3) is explicitly acknowledged in a dramatised narrative of the circumstances in which the hospital gazette was born; in fact the visibility of the French wounded goes beyond the national borders, with an article reviewing La Greffe Générale published in the English-speaking newspaper The Morning (reprinted in LGG 8,4). The strong links established with the national press would later benefit the Association des Gueules Cassées in its fundraising efforts especially (Gehrhardt 2015, 159).

Individual readers are also encouraged to help reach out to the wider public and publicise the cause of wounded soldiers. To this effect, a space is left blank at the end of each issue, for the wounded to write a note to whomever he is sending the copy to. The newspaper thus provides a practical way for patients to communicate with their families or friends. The fact that La Greffe Générale seeks to appeal to people beyond injured soldiers is further visible in articles advising people on how to behave when meeting a disfigured serviceman. Recent research in psychology (Stock et al. 2013) has shown that the difficulties arising in the relationships between people with visible facial differences and their interlocutors are often due to the latter's feeling of helplessness and not knowing what to say and do. La Greffe 
Générale, in 1918, was already giving its readers advice as to how to behave upon encountering a facially injured soldier in the streets. The editors confer the following mission to their journal:

Dites-lui bien, à ce malheureux restrictionné de l'arrière, que vos parents [the wounded] désirent avant tout être compris, connus sous leur jour véritable, qu'ils vous ont conçu simplement dans le but de communiquer aux Français en veston une gaieté nullement feinte, nullement factice en un mot réelle et sincère.

Dites-lui que nous ne voulons pas exciter la pitié de nos contemporains, étant nous-mêmes très satisfaits de nos blessures. Nous n'avions certes pas, au temps lointain de la paix, pareille excuse aux défectuosités de notre anatomie: aujourd'hui nous pouvons tous - Oui, ma chère - donner l'illusion d'un exApollon victime de la guerre (LGG 1, 1).

In this inaugural text, the editors state their determination to not be objects of pity. On the contrary, they declare to be content with their situation. Speaking on behalf of all the wounded, the journalist Louis Latzarus states: 'Ce n'est pas de la pitié que vous demandent les blessés qu'une balle incivile a momentanément privés d'un charme ou deux. Ce qu'ils vous demandent, c'est tout simplement de l'indifférence' (LGG 2,1). The seriousness of the wounds is played down, as well as the often permanent disfigurement they caused. Latzarus's article nevertheless articulates the wounded soldiers' requests and gives readers clear indications as to how to - and how not to - behave in the presence of facially wounded soldiers.

In the sometimes strained relationships between military patients and civilians, a shift towards greater closeness can be observed from early 1918 onwards. The contributors to $L a$ Greffe Générale regularly criticise shirkers, the bombardments nevertheless provide an opportunity to insist on their unity with the Parisian population. Civilians are propelled on the frontline, sharing in the soldiers' experience of being under attack, leading the newspaper to stress the courage shown by the city and its inhabitants. The heroism of frontline combatants is extended to bombed Paris, as illustrated in a drawing portraying a soldier and a young girl both wearing a bandage across their face and their left arm in a sling (LGG 8,4). One was injured on the battlefield, the other in the bombing of her home. This sketch by artist Tito Saubidet underlines not the gap between combatants and civilians, but rather a shared experience.

Ultimately, La Greffe Générale singles out the Val-de-Grâce patients not because of their disfigured faces, but for their courage, their patriotism and their resilience. It is perhaps this positive portrayal that enabled La Greffe Générale to enjoy 'un succès considérable dans les hôpitaux et dans le public' (Le Rappel 1921,1) and to be recognised as a useful communication tool by the authorities themselves, as shown in a letter by head of the frontline press Pierre Chapelle (Chapelle 1917 in LGG 1, 2). A review of La Greffe Générale published in Le Figaro underlines two functions of the hospital newspaper: to enable the wounded to express themselves, and to provide the general public with an example to follow. Three groups are thus connected through the medium of the Val-de-Grâce journal: frontline servicemen, wounded combatants and civilians, this mediating function foreshadowing that of the Association des Gueules Cassées which later endeavoured to bridge the gap between disfigured ex-servicemen, other veterans and the rest of society. 


\section{Conclusion}

The ambitions that the editors of La Greffe Générale had for their gazette seemed to come to a halt when its publication stopped in July 1918. However the image of facially wounded it helped shape, and the relationships it contributed to build amongst wounded soldiers, and between them and the rest of society, found a new and more perennial expression in the foundation of the Association des Gueules Cassées in 1921. Indeed, many of the features displayed in the hospital newspaper can be observed in the Association's bulletin, from humour and patriotism to the sense of forming a group separate from others. La Greffe Générale, like the Association des Gueules Cassées, emphasises the distinctiveness of facial injuries, which were perceived as the worst of all wounds because of their wide-reaching physical, psychological, social and economic implications. If La Greffe Générale does not dwell on the functional and aesthetic implications of facial wounds, the Association would later more readily acknowledge the challenges faced by facially disfigured veterans as it sought to obtain better pensions and to raise funds to support the group's activities. The different chronological settings account for this difference in discourses: La Greffe Générale was written at a time when emphasising negative aspects could be seen an unpatriotic, and as the treatments received could still influence the extent of the disfigurement. In contrast, in the early 1920s gueules cassées were asking for their pensions to recognise (and compensate) the aesthetic prejudice suffered, and in the mid-1920s they were appealing to the generosity of the public in order to buy a property, a goal they achieved in 1927.

Largely thanks to the success of the Association, gueules cassées are still sometimes thought of as a metonym for all mutilated French ex-combatants. Setting up an organisation for disfigured veterans however took time, and no record of any publications dedicated to strengthening the bond between disfigured veterans is recorded between July 1918 and July 1921, when the first bulletin of the Association des Gueules Cassées was sent out. The latter, if it is the first 'official' communication from the newly-formed veterans' group, nevertheless mentions the long-term efforts that led to its creation (Bulletin 1, 1). No specific reason is given for this delay; the lengthy convalescence of many of the wounded may have prolonged their stays in hospital and delayed the emergence of a need for a dedicated organisation. Furthermore, the fact that a number of services are immediately advertised and that the support of prominent figures such as WWI hero Maréchal Pétain is mentioned as already having been secured, is telling of the work done in preparation for this official 'launch' in the Summer of 1921.

The close friendship that existed amongst members of the Association, and especially between some of its founding members who had met at the Val-de-Grâce, enabled gueules cassées to present a united front to the world, thereby shifting the focus away from individuals to either the collective group, or its popular first president and ex-Val-de-Grâce patient Yves Picot. As Julie Anderson (2013) points out in her analysis of British blind soldiers, the mutilated soldier who belonged to a veterans' organisation could be saved the effort of having to renegotiate his own individual identity through embracing an emerging, positive group identity (89). The emergence of this collective voice can be traced back to $L a$ Greffe Générale The bellicose tone adopted and the sense of humour displayed reveal the 
disfigured men's desire to present themselves not as objects of pity, but as men willing and able to further contribute to the war effort and beyond, to the reconstruction of society.

\section{References}

Anderson, Julie. 2014. 'Stoics: Creating Identities at St Dunstan's, 1914-1920', in Stephen McVeigh and Nicola Cooper, Men after War. Abingdon: Routledge.

Audoin-Rouzeau, Stéphane. 1992. Men at War 1914-1918: National Sentiment and Trench Journalism in France during the First World War. Oxford: Berg.

'Aujourd'hui'. 1921. Le Rappel, 21 January.

Benjamin, René. 1917. 'L’Esprit français: un journal de blessés’. Le Journal, 28 September.

Benjamin, Walter (1936) 2006 'The Storyteller: Reflections on the Works of Nikolai Leskov'. Reprinted in The Novel: An Anthology of Criticism and Theory 1900-2000, edited by Hale, Dorothy, 361-78. Malden, Massachusetts: Blackwell Publishing.

Biernoff, Suzannah. 2011. 'The Rhetoric of Disfigurement in First World War Britain'. Social History of Medicine. 24 (3): 666-85.

Bulletin de l'Union des Blessés de la Face. July 1921.. Paris: Private archives of the Association des Gueules Cassées, Paris.

Bulletin de l'Union des Blessés de la Face. February 1923. Paris: Private archives of the Association des Gueules Cassées, Paris.

Carden-Coyne, Ana. 2009. Reconstructing the Body: Classicism, Modernism, and the First World War. Oxford: Oxford University Press.

Chapelle, Pierre. 1917.'Lettre au comité éditorial de La Greffe Générale'. Reprinted in La Greffe Générale. 15 December.

Chuquet, Arthur. 1918. 'A la 5eme Division de Blessés du Val-de-Grâce'. La Greffe Générale, 1 April.

Feo, Katherine. 2007. 'Invisibility: Memory, Masks and Masculinities in the Great War', Journal of Design History, 20 (1): 17 - 27, https://doi.org/10.1093/jdh/ep1039

Fuller, J.G. 1991. Troop Morale and Popular Culture in the British and Dominion Armies 1914-1918. Oxford: Clarendon Press.

Freud, Sigmund. 1960. Jokes and the Unconscious. London: Hogath Press Limited. First published in 1905. 
Garrick, Jacqueline. 2006. 'The Humor of Trauma Survivors', Journal of Aggression, Maltreatment and Trauma, 12 (1-2), 169-82.

Gehrhardt, Marjorie. 2015. The Men with Broken Faces: Gueules Cassées of the First World War. Oxford: Peter Lang.

Gelly, Georges. 1926. Appel en faveur du Foyer des Gueules Cassées. Etampes : Maurice et Cerf. Paris, Bibliothèque Inter-Universitaire de Médicine, 156766/306-16.

La Greffe Générale. December 1917-July 1918 (8 issues). Paris: Bibliothèque nationale de France.

Martin, Rod. 2007. The Psychology of Humor: an Integrative Approach. London: Elsevier.

Mosse, George. 1998. The Image of Man: The Creation of Modern Masculinity. Oxford: Oxford University Press.

Powell, Julie. 2016. 'About-Face: Gender, Disfigurement and the Politics of French Reconstruction, 1918-24'. Gender \& History 28: 604-622. doi:10.1111/1468-0424.12241

Reznick, Jeffrey (2004) 2011. Healing the Nation: Soldiers and caregiving in Britain during the Great War. Manchester: Manchester University Press.

Roubaud, Noële and Raymond Bréhamet. 1960. Le colonel Picot et les gueules cassées. Paris: Nouvelles Editions Latines.

Seal, Graham. 2013. The Soldiers'Press: Trench Journals in the First World War. Basingstoke: Palgrave McMillan.

Stenay-Gatuing, Marcel. 1918. 'Leur rire'. La Greffe Générale, 1 April.

Stock, Nicola M., Katie Whale, Elizabeth Jenkinson, Nicola Rumsey and Fiona Fox. 2013. 'Young people's perceptions of visible difference'. Diversity and Equality in Health and Care 10 (1): 41-51.

Talley, Heather. 2014. Saving Face: Disfigurement and the Politics of Appearance. New York: New York University Press.

Winter, Jay. 1999. 'Forms of kinship and remembrance in the aftermath of the Great War'. In War and Remembrance, edited by Jay Winter and Emmanuel Sivan, 40-60. Cambridge: Cambridge University Press.

\section{Figure caption:}


Figure 1: La Greffe Générale, 1 (December 1917), 3, Bibliothèque nationale de France collections 